\title{
Early Cretaceous ammonites and dinoflagellates from the Western Tatra Mountains, Poland
}

Zdeněk Vašíček, Błażej Błażejowski, Andrzej Gaździcki, Maria Król, Jerzy Lefeld, Petr Skupien, and Andrzej Wierzbowski

Acta Palaeontologica Polonica 65 (4), 2020: 799-810 doi:https://doi.org/10.4202/app.00754.2020

The first Early Cretaceous (Valanginian-Hauterivian) ammonite fauna from the lower part of the Kościeliska Marl Formation (Wściekły Żleb Member) of the Lower Sub-Tatric

(Krížna) Nappe, in the Lejowa Valley of the Tatra Mountains are described. The fauna is precisely placed in the succession and consists of five species: Olcostephanus densicostatus, Spitidiscus cf. cankovi, Criosarasinella cf. subheterocostata, Crioceratites primitivus, and Crioceratites coniferus and additionally an aptychus Didayilamellaptychus seranonis. Remarkable are the valves of anomiid bivalves attached to body chamber of large size heteromorph ammonite $C$. primitivus . Moreover, a variety of stratigraphically important organic-walled dinoflagellate cysts are recovered from this locality. Dinoflagellates: Cymososphaeridium validum, Circulodinium vermiculatum, and representatives of Bourkidinium define the Upper Valanginian-Lower Hauterivian Sentusidinium sp. A Dinocyst Subzone of the Cymososphaeridium validum Zone. The character of deposits, the palynofacies, and associations of dinoflagellate cysts indicate a calm marine outer neritic environment.

Key words: Ammonoidea, Anomiidae, Dinoflagellata, Valanginian, Hauterivian, Western Carpathians.

Zdeněk Vašíček [zdenek.vasicek@ugn.cas.cz], Institute of Geonics, Academy of Sciences of the Czech Republic, Studentská 1768, CZ-708 00 Ostrava-Poruba, Czech Republic. Błażej Błażejowski [bblazej@twarda.pan.pl] (corresponding author) and Andrzej Gaździcki [gazdzick@twarda.pan.pl], Institute of Paleobiology, Polish Academy of Sciences, Twarda 51/55, 00-818 Warszawa, Poland. Maria Król [mkrol@tpn.pl ], Tatra National Park, Kuźnice 1, 34-500 Zakopane, Poland. Jerzy Lefeld [222gama@gmail.com ], Institute of Geological Sciences, Polish Academy of Sciences, Twarda 51/55, 00-818 Warszawa, Poland. Petr Skupien [petr.skupien@vsb.cz], Department of Geological Engineering, Faculty of Mining and Geology, VŠB-Technical University of Ostrava, 17. listopadu 15, CZ-708 33 Ostrava-Poruba, Czech Republic. Andrzej Wierzbowski [andrzej.wierzbowski@uw.edu.pl], Faculty of Geology, University of Warsaw, Żwirki i Wigury 93, 02-089 Warszawa, Poland. 
This is an open-access article distributed under the terms of the Creative Commons

Attribution License (for details please see creativecommons.org), which permits unrestricted use, distribution, and reproduction in any medium, provided the original author and source are credited.

FarF Full text $(2,387.1 \mathrm{kB})$ 